Annual report

\title{
We're off: Annual report October 2001 to September 2002
}

\section{A J Knox, J R Britton}

$\mathrm{T}$ his has been yet another successful year for Thorax. The number of submissions to the journal has remained high, and the number of original papers is still rising (table 1). The geographical distribution of submissions reflects the international flavour of the journal (table 2) and, relative to previous years, ${ }^{12}$ our acceptance rate has been even lower this year (table 3). Median time to first decisions is now at an all time low, reflecting our policy of trying to give a rapid decision and also only publishing the best papers in the journal (table 4). The journal impact factor has risen further to 4.09 and we are still third amongst the respiratory journals, just behind the two American Thoracic Society publications. ${ }^{3}$ We have continued to publish strong review series, ${ }^{4-7}$ management guidelines, ${ }^{8-10}$ and the Year in Review. ${ }^{11}$

This is our final year as editors of Thorax, and we therefore take this opportunity to express our gratitude-not only for this year but also for the whole of our term of office- to the Associate Editors for their hard work and support, and the Advisory Board for providing expertise on which to draw. Our Technical Editor, Liz Stockman, has tirelessly edited hundreds of papers ensuring the final quality of the published work has been excellent. We thank the Editorial Assistants who have been running the journal for the last year, Hilary, Marie and Laura. Hilary in particular has done a superb job in keeping the journal on track over

Table 1 Impact factor and articles submitted by category

\begin{tabular}{lrrrrrrr}
\hline & 1996 & 1997 & 1998 & 1999 & 2000 & 2001 & 2002 \\
\hline Impact factor & 1.96 & 2.31 & 2.86 & 3.44 & 3.98 & 4.09 & \\
Original research & & & & & & & \\
Full papers & 415 & 411 & 398 & 453 & 505 & 573 & 592 \\
Short papers & 51 & 40 & 31 & 36 & 34 & 36 & 44 \\
Rapid communications & 5 & 5 & 7 & 3 & 6 & 9 & 6 \\
Case reports & 247 & 212 & 211 & 149 & 165 & 186 & 146 \\
Editorials/reviews & 38 & 53 & 81 & 57 & 56 & 55 & 33 \\
Review series & 31 & 26 & 13 & 19 & 14 & 15 & 40 \\
Supplement articles & 41 & 29 & 17 & 16 & 46 & 0 & 16 \\
Case report commentaries & 11 & 7 & 7 & 0 & 0 & 0 & 0 \\
Letters & 50 & 55 & 72 & 9 & 96 & 95 & 70 \\
Total & 889 & 838 & 837 & 812 & 922 & 974 & 947 \\
\hline
\end{tabular}

Table 2 Geographical distribution of submissions

\begin{tabular}{|c|c|c|c|c|c|c|c|}
\hline & 1996 & 1997 & 1998 & 1999 & 2000 & 2001 & 2002 \\
\hline UK & 320 & 303 & 265 & 326 & 348 & 323 & 325 \\
\hline Western Europe & 264 & 236 & 242 & 230 & 268 & 345 & 298 \\
\hline Spain & 42 & 45 & 44 & 37 & 38 & 46 & 50 \\
\hline The Netherlands & 44 & 49 & 41 & 40 & 51 & 50 & 49 \\
\hline Italy & 48 & 19 & 38 & 40 & 36 & 65 & 55 \\
\hline France & 28 & 24 & 27 & 26 & 34 & 33 & 20 \\
\hline Turkey & 14 & 22 & 20 & 17 & 27 & 36 & 27 \\
\hline Israel & 17 & 15 & 10 & 13 & 8 & 16 & 12 \\
\hline Eire & 8 & 7 & 5 & 2 & 5 & 2 & 12 \\
\hline Switzerland & 13 & 9 & 5 & 5 & 9 & 18 & 9 \\
\hline Germany & 26 & 23 & 20 & 29 & 31 & 37 & 43 \\
\hline Belgium & 12 & 11 & 10 & 10 & 5 & 14 & 8 \\
\hline Greece & 7 & 6 & 15 & 6 & 12 & 13 & 11 \\
\hline Austria & 5 & 5 & 3 & 4 & 10 & 7 & 2 \\
\hline Portugal & 0 & 0 & 2 & 0 & 0 & 0 & 0 \\
\hline Malta & 0 & 0 & 2 & 1 & 1 & 0 & 0 \\
\hline Andorra & 0 & 0 & 0 & 0 & 1 & 0 & 0 \\
\hline USA and Canada & 71 & 84 & 76 & 81 & 87 & 68 & 74 \\
\hline Japan & 53 & 64 & 46 & 54 & 56 & 69 & 74 \\
\hline Australasia & 31 & 60 & 48 & 38 & 60 & 57 & 45 \\
\hline Scandinavia & 32 & 39 & 36 & 38 & 41 & 49 & 41 \\
\hline Asia & 26 & 26 & 35 & 30 & 39 & 26 & 41 \\
\hline Eastern Europe & 10 & 3 & 6 & 4 & 9 & 16 & 2 \\
\hline South America & 10 & 3 & 3 & 1 & 5 & 7 & 6 \\
\hline Africa & 4 & 4 & 3 & 3 & 4 & 5 & 1 \\
\hline Middle East & 5 & 9 & 5 & 7 & 5 & 8 & 9 \\
\hline
\end{tabular}




\begin{tabular}{|c|c|c|c|}
\hline & Case reports & Papers & Short papers \\
\hline Total & 146 & 592 & 44 \\
\hline Rejected & $130(89 \%)$ & $396(66 \%)$ & $40(90 \%)$ \\
\hline Accepted & $5(3 \%)$ & $47(7 \%)$ & $1(2 \%)$ \\
\hline Pending & $11(7 \%)$ & $149(25 \%)$ & $3(6 \%)$ \\
\hline
\end{tabular}

\begin{tabular}{llllllll}
\hline Table 4 & \multicolumn{7}{l|}{ Median time to first decision (days) } \\
\hline & $1996 / 7$ & $1997 / 8$ & $1998 / 9$ & $1999 / 2000$ & $2000 / 1$ & $2001 / 2$ \\
\hline Full papers & 44.5 & 56 & 48.5 & 56 & 76 & 15 \\
Short papers & 38 & 24 & 11.5 & 28 & 33 & 7 \\
\hline \multicolumn{7}{l}{} \\
\hline
\end{tabular}

the past seven years, through thick and thin. We thank our reviewers who again have done an excellent job and whose names are listed on page 1090. Finally, we would like to thank the scientific respiratory community who sent us their work over the last seven years. Many of you will not have agreed with some of our decisions which, with so many good papers to choose from, have ultimately at times appeared rather arbitrary. By the time this article is published the incoming editorial team (Wisia, Seb and
David) will be in full control of the journal and we wish them all the best. We are sure that the journal will continue to do well in their hands.

Our term as Editors has been interesting, exciting and frustrating, but never dull. If we had had full heads of hair when we started, we would surely have lost it all by now. Fortunately, we had nothing to lose. The success of the journal has sadly not been mirrored by the progress of Nottingham Forest Football Club, although, hopefully, now that we have more time to give them vocal support, things will turn around. They probably won't!

Thorax 2002;57: 1003-1004

Authors' affiliations

A J Knox, J R Britton, Executive Editors

\section{REFERENCES}

1 Britton J, Knox AJ. Annual report October 1999 to September 2000. Thorax 2000;55:986

2 Knox AJ, Britton J. Annual report October 2000 to September 2001. Thorax 2001;56:901.

3 Knox, AJ, Britton J. Journal impact factors for 2000: Thorax flying yet higher. Thorax 2001:56:587.

4 Travis WD, Galvin JR. Rare diseases • 13. Non-neoplastic pulmonary lymphoid lesions. Thorax 2001;56:964-71.

5 Lomas DA. Chronic obstructive pulmonary disease. Introduction. Thorax 2002;57:735

6 Griffiths JD, Evans TW. The pulmonary physician in critical care: towards comprehensive critical care. Thorax 2002;57:77-8.

7 Sethi T. Lung cancer. Introduction. Thorax 2002;57:992-3.

8 British Thoracic Society. BTS statement. Pulmonary rehabilitation. Thorax 2001:56:827-34.

9 British Thoracic Society. BTS guidelines for the management of community acquired pneumonia in adults. Thorax 2001;56/Suppl IV):iv1-iv64.

10 British Thoracic Society. BTS guidelines for the management of community acquired pneumonia in childhood. Thorax 2002;57 (Suppl I):i1-i24.

11 Mitchell DM, Shaheen SO, Woodcock AA, eds. 2001 Year in Review: selected topics in respiratory medicine from 2000 . Thorax 2001;56(Suppl II):ii 1-ii78.

Online submission

\section{Thorax online submission}

\section{New online submission and review system for Thorax}

$\mathrm{T}$ he Editors of Thorax are pleased to inform authors and reviewers that its new online submission and review system is now in place.

Bench $>$ Press is a fully integrated electronic system which uses the internet to allow rapid and efficient submission of manuscripts and permits the entire peer review process to be conducted online.
Authors can submit their manuscript in any standard word processing software. Graphic formats acceptable are: .jpg, .tiff, .gif, and eps. Text and graphic files are automatically converted to PDF for ease of distribution and reviewing purposes. Authors are asked to approve their submission before it formally enters the reviewing process.
To access the system click on "Submit Your Manuscript Here" on the Thorax home page: http://www.thoraxjnl.com/ or you can access Bench > Press directly at http://submit-thorax.bmjjournals.com/.

We are very excited with this new development and would encourage authors and reviewers to use the online system where possible. It really is simple to use and should be a big improvement on the current peer review process. Full instructions can be found on Bench>Press http://submit-thorax. bmjjournals.com/ and Thorax online at http://www.thoraxjnl.com/. Instructions for registering with the system were also published in the October 2002 issue of Thorax on page 846. Please contact Natalie Davies, Project Manager (ndavies@bmjgroup.com) for further information. 